\title{
Biological Features of Medicinal Plants of Agrimonia L. in South Eastern Kazakhstan
}

\author{
Anar Nurgaiypovna Kaliyeva ${ }^{1}$, Gulzhamal Dyuskaliyeva ${ }^{1}$, Abigail Newsome ${ }^{2}$, Rysmakhambet Zhexembiyev $^{1}$ \& \\ Galiya Dzhumahanovna Medeuova ${ }^{1}$ \\ ${ }^{1}$ Department of Biology, Kazakh State Women's Teacher Training University, Republic of Kazakhstan \\ ${ }^{2}$ Mississippi Valley State University, Itta Bena, USA \\ Correspondence: Kaliyeva Anar Nurgaiypovna, Department of Biology, Kazakh State Women's Teacher Training \\ University, Aiteke bi str., 99, Almaty, 050000, Republic of Kazakhstan. Tel: 73-872-7233-1823.
}

Received: January 31, 2014

Accepted: February 13, 2014

Online Published: March 25, 2015

doi:10.5539/mas.v9n5p63

URL: http://dx.doi.org/10.5539/mas.v9n5p63

\begin{abstract}
The paper deals with morphological and anatomical features of medicinal plant Agrimonia L. that grows in South Eastern Kazakhstan. Morphological and anatomical specifications of vegetative organs were analyzed, and microphotographs of the objects being studied were taken. The overall purpose of this experiment is to clone a portion of the lyceraldehydes-3-phosphate dehydrogenase gene (GAPDH). Because it is a vital metabolic enzyme involved in one of the most basic of biological processes- glycolysis in respiration the GAPDH protein is highly conserved between organisms, especially vital domains of the enzyme, such as the active site.
\end{abstract}

Keywords: Agrimonia L, anatomical structure, genomic deoxyribonucleic acid, glyceraldehyde-3-phosphate dehydrogenase, pan-genomes analysis pipeline, random amplified polymorphic DNA analysis

\section{Introduction}

The flora of Kazakhstan has very rich genetic pool and unique stock of useful plants with medicinal properties.For deeperstudy of biological features of plants, and their individual development, the study of morphological and anatomical structure helps identify systemic features, environmental character, and improve the quality of pharmacological use of medical substances extracted from the plants. Resource base of medicinal plants in the Republic of Kazakhstan is the fund resources, harvested from wild plants, and the fund resources, collected by cultivated medicinal plants. Medicinal plants are harvested, not only for the processing of the medical industry and direct sales through pharmacies, but also for the personal needs of the general population (Kukenov \& Averin, 1985). Certain anatomical and diagnostic signs of vegetative parts of medicinal plants improve the use of sorted materials in pharmacology. Our country and definition of the quality of medical plants and acquaintance has a lot of scientific papers for the study. Deep knowledge of the biological characteristics of plants and knowledge of individual features in series of morphological and anatomical structure, allow the definition of a systematic characteristic, environmental and quality improvement in the use of therapeutic pharmaceutical agents taken from plants (Mikhailov, 1975). Botanists and physicians are increasingly interested in agrimony - Agrimonia L. (Kukenov, 1996). In Kazakhstan, two species of agrimony - Agrimonia L. grow, namely, A.asiatica Juz., and A.pilosa Ldb (The Flora of Kazakhstan, 1961). It was established that A.asiatica Juz. Contains large amounts of tanning substances, flavonoids, phenolic acids, and polysaccharides (Gadetskaya, 2009). A.pilosa Ldb. Contains phenolic substances such as agrimonin, catechine, querectin, and rutin (Xu et al., 2005, Murayama et al., 1992). A.pilosa Ldb. Is an indigenous medicinal plant with various properties including anti-oxidative (He et al., 2012), anti-inflammatory, homeostatic, pain relieving, and anti-tumoralones (Taira et al., 2009, Jung et al., 2010). A.pilosa Ldb. Is widely used as natural fragrance, and for prevention of various diseases such as bleeding, chronic fatigue syndrome, and hepatic diseases (Park et al., 2004) and was used for treatment of various cancers and other diseases in Asian countries (Kyoung et al., 2011). According to researchers, tiliroside extracted from A.pilosa Ldb. May be beneficial in treatment of complications of diabetes because it stimulates the secretion of adiponectin and translocation of GLUT4 (Song et al., 2013). Agrimonia pilosa Ldb. Can be used to improve estrogen deficiency-related menopausal symptoms or to treat diseases in postmenopausal women (Lee et al., 2012). To study the chemical constituents in A.pilosa Ldb. Nine flavonoids were obtained and identified as tiliroside, kaempferol 3-O-alpha-L-rhampyranoside, quercetin 3-O-alpha-L-rhampyranoside, quercetin 
3-O-beta-D-glucopyranoside, kaempferol 3-O-beta-D-glucopyranoside, kaempferol, apigenin, luteolin, quercetin (Pan et al., 2008).

The study of the plants used in indigenousor official medicine is becomes increasingly important. One of hardly studied medicinal plants in the flora of Kazakhstan is specie of family of Rozeaceae, Agrimonia L. Or agrimony. In this paper, morphological and anatomical structure of vegetative organs of specie Agrimonia L., that grows in various environmental conditions were studied for identification of their biological features.

For each of wild-type medicinal plant known, we need to know the dynamics of its growth and development over the years, the influence of environmental factors and the age dynamics of the content of biologically active substances. To do this, we must investigate not only the anatomical characteristic of the plants, such as Agrimonia L., but also the molecular characteristics of the plants, the genes. Due to the difficult nature of being able to clone and sequence DNA from Agrimonia L., this preliminary project was done to identify the experimental conditions necessary to accomplish the amplification and sequencing of genes of Agrimonia L. As such, the experimental conditions necessary to isolate and sequence the of lyceraldehydes-3-phosphate dehydrogenase of Agrimonia $\mathrm{L}$. was undertaken. The significance of 64lyceraldehydes-3-phosphate dehydrogenase (GAPDH) is very relevant to the biological process of glycolysis respiration. The GAPDH gene is located in modern humans and all other organisms. The product of this gene catalyzes an important energy-yielding step in carbohydrate metabolism, the reversible oxidative phosphorylation of GAPDH in the presence of inorganic phosphate and nicotinamide adenine dinucleotide (NAD). Since this is a constitutively expressed gene that is present in all organisms, this gene was the choice for identify the optimal experimental conditions for this study.

\section{Materials and Methods}

The material of the study were specimens of A.asiatica Juz. That grows in natural habitat near Koldi Village, Almaty Region, within altitude range is $832 \mathrm{~m}$ above sea level, and specimens of A.pilosa Ldb., that growsin the mountains of south east Kazakhstan within National Natural Reserve (NNR) Kolsai Lakes, Almaty Region, at the altitude of $1,818 \mathrm{~m}$ above sea level.The specimens were sampledaccording to development stages (vegetation, budding, flourishing, and fructification), and according tothe morphological groups (leaves, stalks, flowers, and roots) in 2013. The species of the plants being studied were identified according to Flora of Kazakhstan and illustrated keys to plants of Kazakhstan (Illustrative of the plants of Kazakhstan, 1969). Based on material fixed in a mixture of spirit, water, and glycerol with ratio 1:1:1 according to Strasburger and Flemming, and anatomical and morphological studies were conducted according to the methods of M.N. Prozina (Prozina, 1960). The anatomic slices of aboveground and underground organs of plants were made by microtome MZP-01 'Technom'(Yekaterinburg). The temporary preparations wereimmersedinglycerol. The thickness of the anatomic slices ranged from 10 to 15 micrometers. Over 1,000 temporary and permanent preparations were made for microphotography and morphometric analysis. For quantitative analysis, morphometric indicators were measured by MCX 100 Micros microscope (Austria) with camera adapter (with lens4x/0.10, and multiplication ratio EW $10 \mathrm{x} / 20$ ). The statistical analysis of morphometric indicators was performed according to methods of G.F.Lakin (Lakin, 1990).

The samples of A.asiatica Juz. Were collected growing in the village of Koldy (30 km from Almaty, at an altitude of $832 \mathrm{~m}$ above sea level). In order to clone a gene from an organism, DNA must first be isolated from that organism. This genomic DNA is isolated from plants using column chromatography. Plant material is weighed, and then the material is ground in lysis buffer with high salt and protein inhibitors using a micro pestle. The solid plant material is removed by centrifugation, then ethanol is added to the lysate and lysate is applied to the column. The ethanol and salt encourage DNA to bind to the silica in the chromatography column. The column is then washed and the DNA is eluted using sterile water at $70^{\circ} \mathrm{C}$.

For PCR to be successful, the DNA extracted needs to be relatively intact. The best sources for DNA extraction are young green leaves. It is better to use tissue that is still growing, as the nucleus: cytoplasm ratio will be more favorable, cells walls will be thinner, and the amount of potentially harmful secondary products will be less. The amplification of genomic DNA was performed with the help of thermal cycler (My Cycler. Bio-Rad.USA) in the scientific laboratories Mississippi Valley State University, USA).

\section{Results and Discussion}

Asian agrimony (A. asiatica Juz.) belongs to the family of Rosaceae Juss., and is a perennial, tall plant (up to 80-117 cm high), with upright stalk and prolonged branches. One plant has 10-14 stalks. The rootstock is branched, and is $15-20 \mathrm{~cm}$ long. The upper side of leaves is green, dense and hairy, and the lower side of leaves is gray-green, with dense and velvety hairs, and small yellow glands. There are 70-157 leaves, and they are 2-8 cm long, and 1-4 $\mathrm{cm}$ wide, and are elliptical, oblong egg-shaped, and large and sharp-toothed. The inflorescence is a long spicate 
raceme, with dense flowers and fruits located at the lower part, and loose ones at the upper part. The flowers grow on short pedicles, and there are 5 sepals, and 5 gold-yellow petals, and the fruits are bulbous and have spinules.

A. pilosa Ldb. is a perennial plant belonging to family of Rosaceae Juss., and it is 63 to $90 \mathrm{~cm}$ high. Its stalk is roundish and branchy, and is covered by hairs. The leaves are loose, interruptedly pinnate, bare, or infrequently hairy, and green on both sides, while upper side is darker. One plant has 96-102 leaves, and the inflorescence is spicate raceme, with diameter of 6-8 $\mathrm{mm}$, and sub sessile yellow flowers, which have double pentamerous envelope, and the plant has subtle scent. The receptacle is very concaved, and its outer side has dense hooky bristles that become harder near the fruits. By these bristles the fruits cling to animals' hairs or human clothes, and thus, are disseminated. The fruits are upright, and droop only when they are fully mature. The petals are oblong, light yellow, and the root system is tap-rooted, and the rootstock is branchy.

\subsection{Stage I - Morphometric Indicators of Anatomical Structure}

Morphometric indicators of anatomical structure of leaf are shown in Table 1.

Table 1. Anatomical indicators of leaf of Agrimonia L

\begin{tabular}{llllllll}
\hline $\begin{array}{c}\text { Plant name, and } \\
\text { sampling location }\end{array}$ & Conducting bundle & \multicolumn{2}{c}{$\begin{array}{c}\text { Mesophyll thickness, } \\
\text { micrometers }\end{array}$} & $\begin{array}{c}\text { Epidermis thickness, } \\
\text { micrometers }\end{array}$ & $\begin{array}{c}\text { Thickness of } \\
\text { lamina, } \\
\text { micrometers }\end{array}$ \\
\cline { 2 - 6 } & Length & Width & $\begin{array}{l}\text { Columnar } \\
\text { mesophyll }\end{array}$ & $\begin{array}{l}\text { Spongy } \\
\text { mesophyll }\end{array}$ & Upper & Lower n & \\
\cline { 1 - 5 } A.asiatica Juz., & 273.65 & 264.56 & 139.03 & 66.49 & 44.41 & 43.64 & 637.36 \\
Koldi Village & \pm 0.95 & \pm 1.23 & \pm 0.35 & \pm 0.75 & \pm 0.58 & \pm 0.89 & \pm 1.27 \\
A.pilosa Ldb., & 562.84 & 435.80 & 104.45 & 87.58 & $141.47 \pm$ & 139.02 & 400.35 \\
NNRKolsai Lakes & \pm 0.06 & \pm 1.66 & \pm 0.06 & \pm 0.01 & 0.03 & \pm 0.03 & \pm 0.04 \\
\hline
\end{tabular}

Note: (with lens4x/0.10, and multiplication ratio EW 10x/20).

The anatomical study of leaf of A.asiatica Juz. shows the cells of upper and lower epidermis, and epidermal cells of rounded shape. Under the upper epidermis, 2-tiered columnar mesophyll is located, and under lower epidermis, spongy mesophyll is located. The transversal section shows that the leaf has dorsoventral structure. The lower epidermis has pronounced simple trichomes. At the center of lamina, a larger collateral conducting bundle with well-developed xylem vessels is located (Figure 1a).

When looking at transversal section of leaf of A.pilosa Ldb., the epidermis cells, and columnar and spongy mesophyll are seen from above. The leaf has dorsoventral structure, and the main vein has two conducting bundles that are collateral, and are of closed type. The xylem elements are well developed, while simple and blunted cone-shaped trichomes are located on both sides of leaf (Figure 1b). 


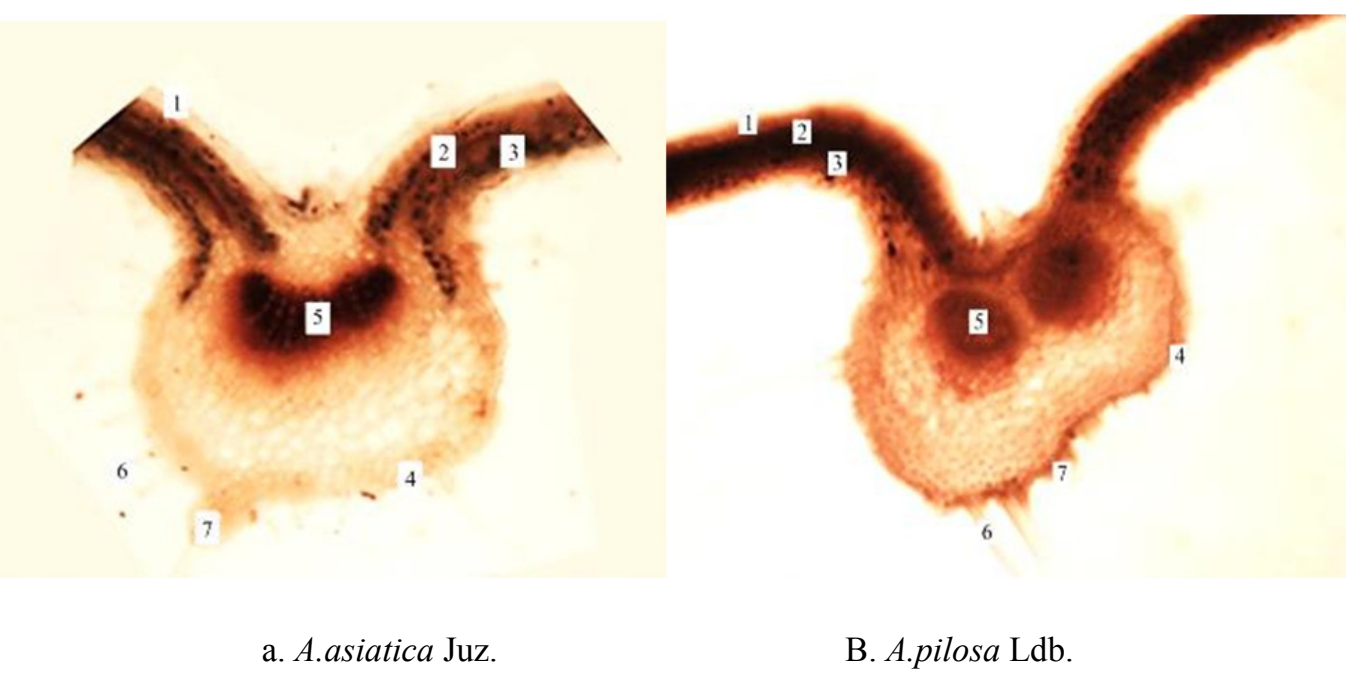

Figure 1. Anatomical structure of leaf: 1. upper epidermis, 2. columnar mesophyll, 3. spongy mesophyll, 4. lower epidermis, 5. conducting bundles, 6. hairs, 7. trichomes

Morphometric indicators of anatomical structure of stalk are shown in Table 2.

Table 2. Morphometric indicators of anatomical structure of stalk of Agrimonia L

\begin{tabular}{|c|c|c|c|c|c|c|}
\hline \multirow{2}{*}{$\begin{array}{l}\text { Plant name, and } \\
\text { sampling location }\end{array}$} & \multicolumn{2}{|c|}{$\begin{array}{l}\text { Length of conducting } \\
\text { bundles, micrometers }\end{array}$} & \multicolumn{2}{|c|}{ Xylem, micrometers } & \multirow{2}{*}{$\begin{array}{l}\text { Phloem, } \\
\text { micrometers }\end{array}$} & \multirow{2}{*}{$\begin{array}{l}\text { Thickness of } \\
\text { phloem fiber, } \\
\text { micrometers }\end{array}$} \\
\hline & Length & Thickness & Length & Thickness & & \\
\hline $\begin{array}{l}\text { A.asiatica Juz., } \\
\text { Koldi Village }\end{array}$ & $\begin{array}{l}970.42 \\
\pm 5.31\end{array}$ & $\begin{array}{r}669.77 \\
\pm 8.11\end{array}$ & $\begin{array}{l}646.0 \\
\pm 2.07\end{array}$ & $\begin{array}{l}373.81 \\
\pm 1.66\end{array}$ & $\begin{array}{l}136.76 \\
\pm 1.03\end{array}$ & $\begin{array}{r}255.60 \\
\pm 0.92\end{array}$ \\
\hline $\begin{array}{l}\text { A.pilosa Ldb., } \\
\text { NNP Kolsai Lakes }\end{array}$ & $\begin{array}{l}316.67 \\
\pm 0.01\end{array}$ & $\begin{array}{l}256.67 \\
\pm 0.79\end{array}$ & $\begin{array}{l}226.67 \\
\pm 0.94\end{array}$ & $\begin{array}{l}110 \\
\pm 0.74\end{array}$ & $\begin{array}{l}50,01 \\
\pm 2.33\end{array}$ & $\begin{array}{l}63.34 \\
\pm 0.88\end{array}$ \\
\hline
\end{tabular}

Note: (with lens4x/0.10, and multiplication ratio EW 10x/20).

On transversal section of A.asiatica Juz., one-tiered epidermis is seen, which consists of small cells located near some parts of collenchyma. The conducting bundles are located circle-wise. The core consists of loose parenchymal cells of roundish shape (Figure 2a).

When looking at transversal section of stalk, main elements of stalk are well seen: epidermis, cortex, and stele. The epidermis consists of closely located cells, and simple trichomes are distributed along whole epidermis of stalk. The conducting system is located circle-wise in one tier as collateral bundles of various sizes, and between them, parenchymal cells are located. The phloem has smaller cells, twice as smaller as xylem vessels, and there is well-developed phloem sheath. At the center of stalk, there are large, roundish, loose parenchymal cells (Figure 2b). 


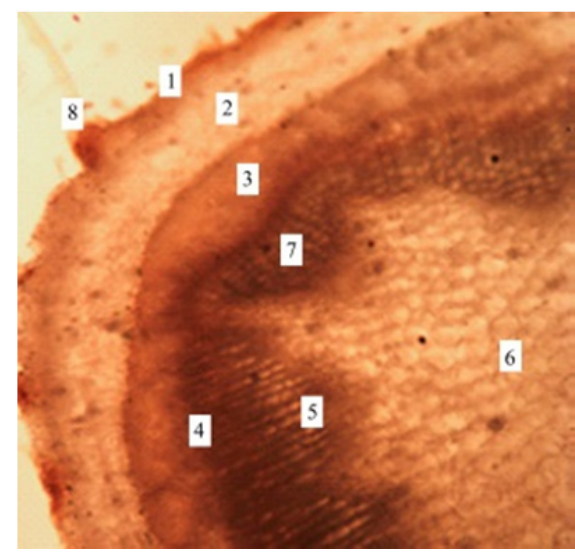

a. A.asiatica Juz.

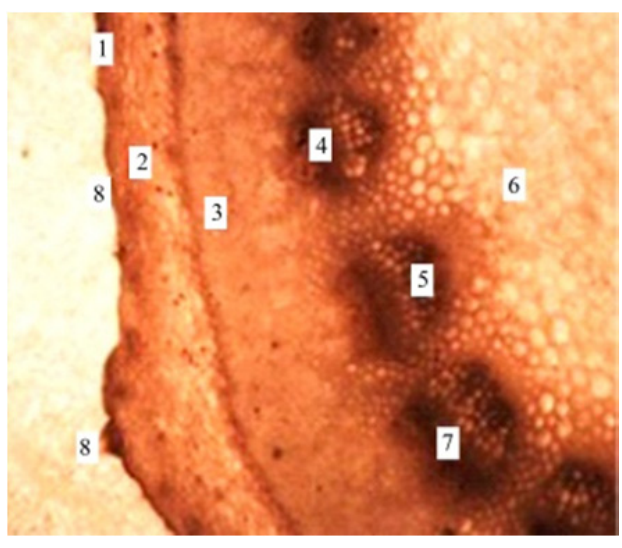

b. A.pilosa Ldb.

Figure 2. Anatomical structure of stalk: 1. epidermis, 2. collenchyma of cortex, 3. sclerenchyma, 4. phloem, 5. xylem, 6. parenchyma of core, 7. conducting bundle, 8. trichomes

Morphometric indicators of anatomic structure of root of A.asiatica Juz. are shown in Tables 3a and 3b.

Table 3a. Anatomical features of root of A.asiatica Juz.

\begin{tabular}{lll}
\hline Thickness of cortex, micrometers & Diameter of stele, micrometers & Diameter of xylem rays, micrometers \\
\hline $266.19 \pm 1.06$ & $3513.01 \pm 54.51$ & $64.70 \pm 0.52$ \\
\hline
\end{tabular}

Note: (with lens $4 x / 0.10$, and multiplication ratio EW 10x/20).

Table 3b. Anatomical features of root of A.pilosa Ldb

\begin{tabular}{llllll}
\hline $\begin{array}{l}\text { Periderm, } \\
\text { micrometers }\end{array}$ & $\begin{array}{l}\text { Cortex, } \\
\text { micrometers }\end{array}$ & $\begin{array}{l}\text { Bark, } \\
\text { micrometers }\end{array}$ & $\begin{array}{l}\text { Phloem, } \\
\text { micrometers }\end{array}$ & $\begin{array}{l}\text { Cambium, } \\
\text { micrometers }\end{array}$ & $\begin{array}{l}\text { Xylem, } \\
\text { micrometers }\end{array}$ \\
\hline $152.87 \pm 0.93$ & $221.83 \pm 0.23$ & $354.13 \pm 1.49$ & $382.17 \pm 0.33$ & $78.21 \pm 0.43$ & $770.72 \pm 0.51$ \\
\hline
\end{tabular}

Note: (with lens $4 x / 0.10$, and multiplication ratio EW 10x/20).

In immature stage of development, the root of A.asiatica Juz. has very pronounced deuteron stoma. The stele of the root is full of structural elements of secondary xylem. The thick part of the root accumulates reserve nutrients in the mass of parenchymal cells of secondary phloem. The phloem elements form the active cortex, and bark, which is a lignified phloem tissue playing the functions of framework and protection of the stele (Figure $3 \mathrm{a}$ ).

In young vegetation condition the structure of root of A.pilosa Ldb.is roundish, and one or two layered exoderm, cortex and bark, and stele are well seen on the transversal section. The core is well developed, and consists of many parenchymal cells. The internal part of the root is occupied by stele. The phloem is located between xylem rays, and the xylem consists of vessels of various size (Figure $3 \mathrm{~b}$ ). 


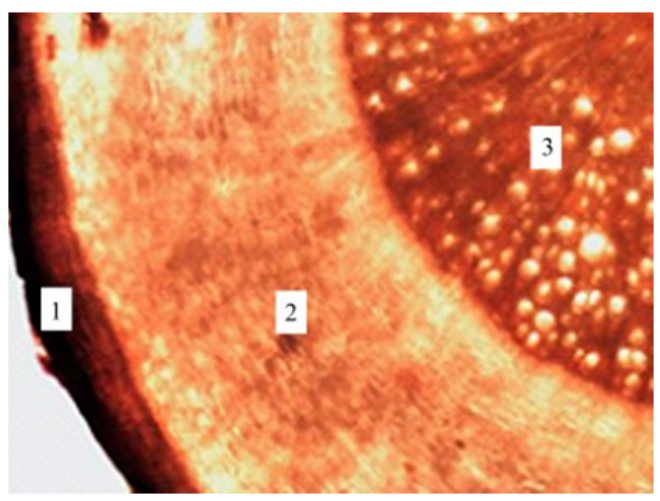

a. A.asiatica Juz.

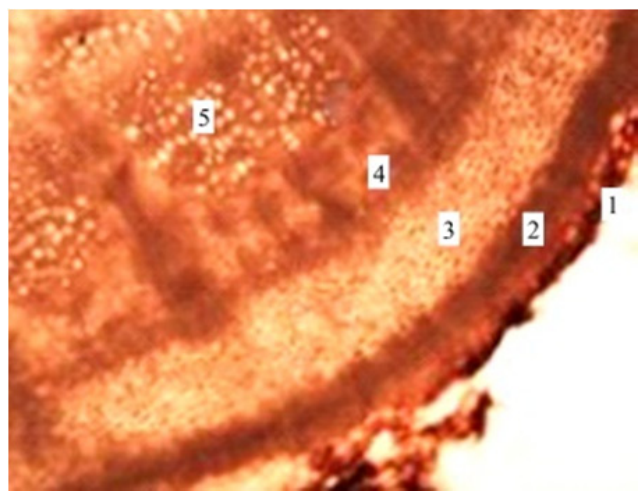

b. A. pilosa Ldb.

Figure 3. Anatomical structure of root: 1. exoderm, 2. collenchyma of cortex, 3. xylem vessels

1. exoderm, 2. cortex (parenchymal cell layer), 3. endoderm, 4. phloem, 5. xylem vessels

\subsection{Stage II - isolation of the GAPDH gene from A.asiatica Juz}

Polymerase chain reaction (PCR) was performed to create multiple copies of a segment of the GAPDH DNA using genomic DNA (gDNA) of A.asiatica Juz. The PCR process consisted of an initial and a nested PCR step. Four samples were used for the initial PCR process: a negative control (sterile $\mathrm{H}_{2} \mathrm{O}$ ), Arabidopsis gDNA, positive control (pGAP plasmid), and the above isolated A.asiatica Juz. A master mix which was prepared according to the protocol of Bio-Rad using GAPDH primers 5'-5'-CTACTGGTGTCTTCACTGACAA-3 and 5"-AGCATTTTTGACGCCAAGGCTG-3", Taq DNA polymerase, dNTPs, buffer, and salts. This was subjected to the following PCR cycling protocol (Table 4).

Table 4. Polymerase Chain Reaction Protocol for the Initial round of cycling

\begin{tabular}{lll}
\hline Initial denaturation: & $95^{\circ} \mathrm{C}$ & 5 minutes \\
\hline Then 40 cycles of: & & \\
Denaturation & $95^{\circ} \mathrm{C}$ & 1 minute \\
Annealing & $52^{\circ} \mathrm{C}$ & 1 minute \\
Extension & $72^{\circ} \mathrm{C}$ & 2 minute \\
Final extension & $72^{\circ} \mathrm{C}$ & 6 minutes \\
Hold & $15^{\circ} \mathrm{C}$ & $(\circ)$ \\
\hline
\end{tabular}

Before nested PCR was done, exonuclease 1was placed in the Arabidopsis tube and the plant tube containing the amplified genomic DNA and incubated at 37 Celsius for 15 minutes to remove the nucleotide overhangs. This mixture was heated at 80 Celsius for 15 minutes to inactivate the exonuclease. A master mix was prepared according to the protocol of Bio Rad using GAPDH primers, Taq DNA polymerase, dNTPs, buffer, and salts. Arabidopsis gDNA, pGAP plasmid and A.asiatica Juz. gDNA were added to the master mix and subjected to nested PCR as noted in Table 5.

Table 5. Polymerase Chain Reaction Protocol for the Nested round of cycling

\begin{tabular}{lll}
\hline Initial denaturation: & $95^{\circ} \mathrm{C}$ & 5 minutes \\
\hline Then 40 cycles of: & & \\
Denaturation & $95^{\circ} \mathrm{C}$ & 1 minute \\
Annealing & $46^{\circ} \mathrm{C}$ & 1 minute \\
Extension & $72^{\circ} \mathrm{C}$ & 2 minute \\
Final extension & $72^{\circ} \mathrm{C}$ & 6 minutes \\
Hold & $15^{\circ} \mathrm{C}$ & $(\circ)$ \\
\hline
\end{tabular}

The products of both the initial and nested PCR reactions were analyzed as shown below (Figure 4a and b). 


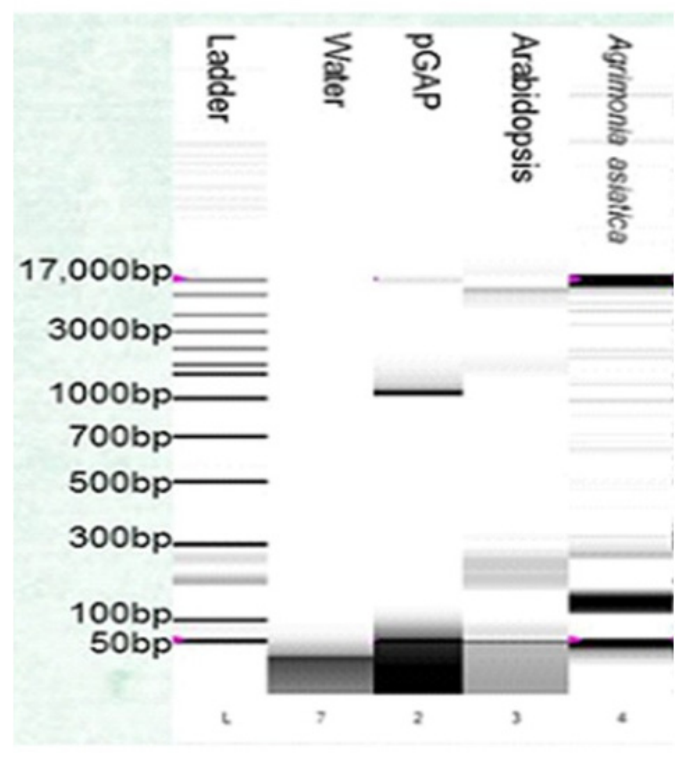

a. Electrophoresis analysis of initial PCR

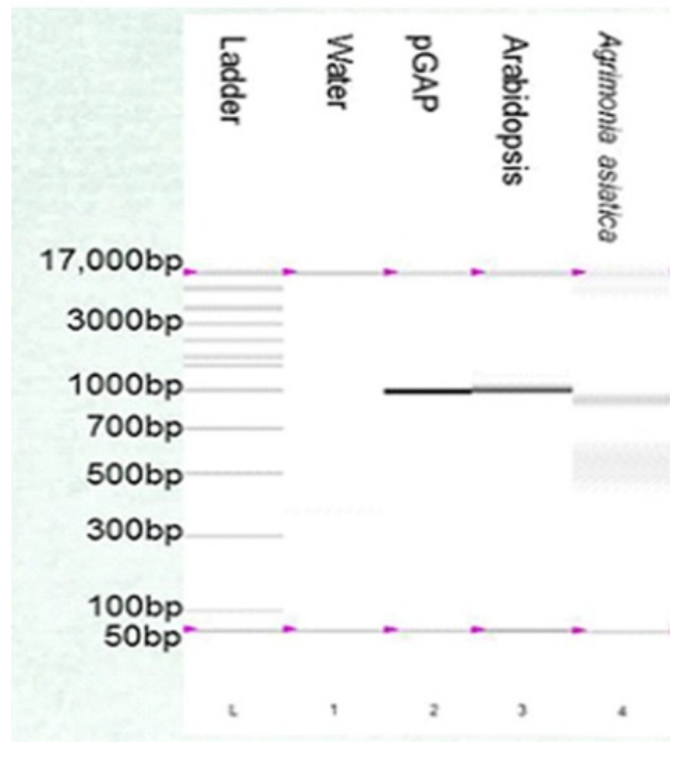

b. Electrophoresis analysis of nested PCR

Figure 4. Electrophoresis Analysis of PCR GAPDH genes from A.asiatica Juz.

Figure 4a shows initial PCR product of the GAPDH gene of the pGAP control $(\sim 1100 \mathrm{bp})$ and a faint product of the genomic DNA of Arabidopsis. However, numerous bands were obtained when using the A.asiatica Juz. gDNA samples. This was not a concern as it was thought that the following nested protocol would drastically reduce the erroneous bands due to the stringency of the cycles and the primers used. Figure $4 \mathrm{~b}$ clearly illustrates a reduction in the erroneous bands and a GAPDH PCR product the A.asiatica Juz. DNA sample (1100bp) with water behaving according as a negative control. This is still under investigation.

\section{Conclusions}

In the study, micromorphologic diagnostic features of A.asiatica Juz. and A.pilosa Ldb. were identified. Leaf of A.asiatica Juz. is oblong and egg-shaped, and sharp toothed along its edges, and simple trichomes are well developed in lower epidermis. The main vein has a large conducting bundle with well-developed xylem vessels leaf of A.pilosa Ldb. is loose, interruptedly pinnate, hypostomatic, and has short simple and blunted cone-shaped trichomes, and at two main vein, there are two conducting bundles, that are collateral, and of closed type.The transversal section of stalk of A.asiatica Juz. and A.pilosa Ldb. shows thatxylem vessels are developed twice as much as phloem elements. The conducting bundles of stalk are collateral, and lay close to the stalk surface, and are distributed evenly, in one tier. A.pilosa Ldb. has developed phloem sheath. The transversal section of the root of A.asiatica Juz. and A.pilosa Ldb. is roundish, and cortex, barks and stele are well seen, and well pronounced, and xylem rays of various sizes are clearly pronounced. The analysis of the data showed that there are no evident differences in anatomical structures of the two species of Agrimonia L. By its medicinal effect, A.pilosa Ldb. issimilarto A.asiatica Juz., and it differs from the latter by only small morphological features, thinner stalk, and footstalks covered by long protruding hairs without any short ones.

The results isolation of genes do provide preliminary evidence that the protocols used here are sufficient to isolate genes, in particular medicinal genes, that might be involved be useful to the population of the area. To perform further investigations of this we try to will isolate some of the genes known to be involved medicinal uses.

\section{References}

Gadetskaya, A. V. (2009). The Pharmaceutical Characteristics of Agrimonia asiatica Juss. The 3rd International Conference: Innovational Development and the Demand for Science in Modern Kazakhstan. Natural and Technical Sciences. Collected Articles. Almaty, 234-235.

He, C., Ji, X., Pan, Y., Wang, H., Wang, K., Liang, M., \& Yang, L. (2010). Antioxidant activity of alcoholic extract of Agrimonia pilosa Ledeb. Med Chem Res. 19(5), $448-461$. http://dx.doi.org/10.1007/s00044-009-9201-0

Illustrative of the plants of Kazakhstan. (1969). Alma-Ata, Vol.1. 
Jung, C. H., Kim, J. H., Park, S, J., Kweon, D. H., Kim, S. H., \& Ko, S. G. (2010). Inhibitory effect of Agrimonia pilosa Ledeb. on inflammation by suppression of iNOS and ROS production. Immunol Invest., 39(2), 159-170. http://dx.doi.org/10.3109/08820130903501790

Kukenov, M. K. (1996). Medicinal plants of Kazakhstan and their use. Almaty. Gylym, 217-218.

Kukenov, M. K., \& Averin, V. Y. (1985). The major essential oil plants of Kazakhstan and their rational use. The main directions of scientific research on essential oil production intensification. Simferopol, 122-123.

Kyoung, J. Nho, Jin, Mi, Chun, H., \& Kyoung, K. (2011). Agrimonia pilosa ethanol extract induces apoptotic cell death in HepG2 cells. Journal of Ethnopharmacology, 138, 358- 363.

Lakin, G. F. (1990). Biometrics. Moscow: Higher School, 352.

Lee, Y. M, Kim, J. B., Bae, J. H., Lee, J. S., Kim, P. S., Jang, H. H., \& Kim, H. R. (2012). Estrogen-like activity of aqueous extract from Agrimonia pilosa Ledeb. in MCF-7 cells. Functional Food \& Nutrition Division, Department of Agro-food Resources, National Academy of Agricultural Science, Rural Development Administration, Suwon, Republic of Korea. BMC Complement Altern Med. Dec 21, 12, 260. http://dx.doi.org/10.1186/1472-6882-12-260.

Mikhailov, V. P. (1975). Study and development of plant resources of Kazakhstan. Wild technical and medicinal plants of Kazakhstan. Alma-Ata, 1-13.

Murayama, T., Kishi, N., Koshiura, R., Takagi, K., Furukawa, T., \& Miyamoto, K. (1992). Agrimoniin, an antitumor tannin of Agrimonia pilosa Ledeb., induces interleukin-1. Anticancer Res., 12(5), 1471-1474.

Pan, Y., Liu, H. X., Zhuang, Y. L., Ding, L. Q., Chen, L. X., \& Qiu, F. (2008). Studies on isolation and identification of flavonoids in herbs of Agrimonia pilosa. Zhongguo Zhong Yao Za Zhi. School of Traditional Chinese Materia Medica, Shenyang Pharmaceutical University, Shenyang, Dec, 33(24), 2925-8. China. PMID: 19294852 [PubMed - indexed for MEDLINE]

Park, E. J., Oh, H., Kang, T. H., Sohn, D. H., \& Kim, Y. C. (2004). An isocoumarin with hepatoprotective activity in HepG2 and primary hepatocytes from Agrimonia pilosa. Archives of Pharmacal Research, 27, 944-946.

Prozina, M. N. (1960). Botanical mikrotehnika. Moscow, 208.

Song, L. L., Li, D., Zhang, M. X., Zhuang, P. W., Yan, Z. L., Li, J. N., Deng, Y. R., \& Zhang, Y. J. (2013). Tiliroside Isolated from Agrimonia pilosa Ledeb.: Enhanced Adiponectin Secretion and GLUT4 Translocation in 3T3-L1 Cells. Latin American journal of pharmacy, 32(4), 524-530.

Taira, J., Nanbu, H., \& Ueda, K. (2009). Nitric oxide-scavenging compounds in Agrimonia pilosa Ledeb on LPS-induced RAW264. 7 macrophages. Food Chem., 115(4), 1221-1227. http://dx.doi.org/10.1016/j.foodchem.2009.01.030

The Flora of Kazakhstan. (1961). The Academy of Sciences of the Kazakh SSR. Almaty, IY, 480-481.

Xu, X., Qi, X., Wang, W., \& Chen, G. (2005). Separation and determination of flavonoids in Agrimonia pilosa Ledeb. by capillary electrophoresis with electrochemical detection. J Sep Sci., 28(7), 647-652. http://dx.doi.org/10.1002/jssc.200400095

\section{Copyrights}

Copyright for this article is retained by the author(s), with first publication rights granted to the journal.

This is an open-access article distributed under the terms and conditions of the Creative Commons Attribution license (http://creativecommons.org/licenses/by/3.0/). 